\title{
Shaking a methane fizz: Seismicity from the Araguainha impact event and the Permian-Triassic global carbon isotope record
}

\author{
E. Tohver ${ }^{\text {a,* }}$, P.A. Cawood ${ }^{\mathrm{a}, \mathrm{b}}$, C. Riccomini ${ }^{\mathrm{c}}$, C. Lana ${ }^{\mathrm{d}}$, R.I.F. Trindade ${ }^{\mathrm{c}}$ \\ a School of Earth E' Environment, University of Western Australia, Australia \\ b St. Andrews University, Scotland, United Kingdom \\ c Universidade de São Paulo, Brazil \\ d Universidade Federal de Ouro Preto, Brazil
}

\section{A R T I C L E I N F O}

\section{Article history:}

Received 22 May 2012

Received in revised form 8 July 2013

Accepted 11 July 2013

Available online 18 July 2013

\section{Keywords:}

Permian-Triassic mass extinction

Impact event

Carbon isotope excursion

Seismicity

Methane

\begin{abstract}
A B S T R A C T
The Late Permian and Early Triassic periods are marked by large fluctuations in the carbon isotope record, but the source $(s)$ of the disturbance to the global carbon cycle and the link to the end-Permian mass extinction are widely debated. This contribution explores the possible isotopic effects of an impact event into the hydrocarbon-rich rocks of the Paraná-Karoo Basin. Recent U-Pb and ${ }^{40} \mathrm{Ar} /{ }^{39} \mathrm{Ar}$ dating of the $40 \mathrm{~km}$ Araguainha impact structure of central Brazil reveals an age of $254.7 \pm 2.5 \mathrm{Ma}\left(2 \sigma\right.$ error) for this event. The calculated energy $\left(10^{5}-10^{6} \mathrm{MT}\right.$ of TNT equivalent) released by this impact is less than threshold values of $10^{7}-10^{8}$ MT TNT equivalent for global mass extinctions. Thus, the Araguainha crater is unlikely to have been the cause of the end-Permian biotic crisis. However, the combined seismic effects from the impact itself and the post-impact collapse of the 20-25 km diameter transient crater to its present $40 \mathrm{~km}$ diameter would result in large magnitude earthquakes $\left(\mathrm{M}_{\mathrm{w}}\right.$ 9.3-10.5) and tsunamis in the shallow marine Paraná-Karoo Basin. Slope failure and sediment liquefaction are predicted to have occurred within a 700-3000 km radius of the crater, causing large-scale release of methane from organic-rich sediments of this basin, including the oil shale horizons of the Iratí Formation. New geological evidence for seismicity in the Paraná Basin at the time of impact is presented, together with a compilation of existing carbon isotope data from the Paraná Basin, which demonstrate a widespread pattern of disturbance consistent with the release of methane. These two datasets suggest that both seismicity and methane release took place within ca. $1000 \mathrm{~km}$ of the impact site, with mass balance calculations suggesting ca. $1600 \mathrm{GT}$ of methane were released into the atmosphere at this time. Methane release at this scale would have significant climate effects and would contribute to a sharp ( $<1 \mathrm{ka})$ negative shift in $\delta^{13} \mathrm{C}$ values at the time of the impact, which should be distinguishable from the more gradual shift over 0.5-1 Ma caused by contemporaneous intrusion of the Siberian traps.
\end{abstract}

(C) 2013 Elsevier B.V. All rights reserved.

\section{Introduction}

The end-Permian mass extinction is the largest of the five mass extinctions that punctuate the Phanerozoic record of life on Earth (Raup and Sepkoski, 1982; Erwin et al., 2002; Alroy et al., 2008). The integration of $\mathrm{U}-\mathrm{Pb}$ geochronology, isotope chemostratigraphy, and biostratigraphy have been critical in defining a globally synchronous Permian-Triassic horizon (e.g., Bowring et al., 1998), which is followed by the first appearance of the basal Triassic conodont Hindeodus parvus (Yin et al., 2001). High precision U-Pb analysis of zircon from volcanic ash layers establishes the $252.6 \pm 0.2 \mathrm{Ma}$ timing of the biotic crisis in the marine realm (Mundil et al., 2004), redefined by Shen et al. (2011) to $252.28 \pm 0.06 \mathrm{Ma}$. The carbon isotope record demonstrates a large decrease in ${ }^{13} \delta \mathrm{C}$ of seawater at this time (Korte and Kozur, 2010), with perturbation continuing into Early Triassic times (Payne

\footnotetext{
* Corresponding author. Tel.: +61 864882677.

E-mail address: eric.tohver@uwa.edu.au (E. Tohver).
}

et al., 2004; Xie et al., 2007; Tanner, 2010). The global nature of the carbon isotope record (Baud et al., 1989; Korte and Kozur, 2010) has been established by studies of high latitude, Gondwanan sites, e.g., New Zealand (Krull et al., 2000), Antarctica (Krull and Retallack, 2000), and South Africa (MacLeod et al., 2000), equatorial sites in the Panthalassan Ocean (e.g., Japan; Algeo et al., 2008), as well as middle to low latitude Tethyan sites including the European Alps, Iran, and the type section in Meishan, eastern China (Magaritz et al., 1992; Wang et al., 1994; Jin et al., 2000; Xie et al., 2007; Cao et al., 2009).

The recent $\mathrm{U}-\mathrm{Pb}$ and ${ }^{40} \mathrm{Ar} /{ }^{39} \mathrm{Ar}$ dating of the impact melts from the $40 \mathrm{~km}$ Araguainha structure at $254.7 \pm 2.5 \mathrm{Ma}$ establishes the Permian-Triassic age of a mid-sized impact event (Tohver et al., 2012). The most lethal effects of meteorite impacts are caused by the sun-blocking blanket of ejecta in the upper atmosphere, resulting in the catastrophic collapse of primary productivity, known as the "nuclear winter" scenario (Toon et al., 1997). Global die-off can ensue from impacts that release $>10^{6}$ Mt TNT equivalent of energy, which is estimated from crater size; e.g., the $180 \mathrm{~km}$ diameter Chicxulub crater released 
ca. $10^{8}$ Mt TNT equivalent (Toon et al., 1997). Thus, the energy release from the $40 \mathrm{~km}$ diameter Araguainha crater was likely too small to have been the cause of the end-Permian mass extinction. However, the hydrocarbon-rich target rocks of the Paraná Basin present a potential source of disturbance to the Permian-Triassic carbon cycle triggered by the Araguainha impact event. This contribution examines the mechanism and magnitude of impactogenic seismicity and the potential for carbon release, demonstrating that even moderate impact events can provide substantial inputs to the global carbon cycle, with consequences beyond the throttling off of primary productivity.

This paper constrains the possible effects of the Araguainha impact event on the global carbon budget by establishing limits to the amount of isotopically light carbon that could have been released by impactogenic seismicity. First, the magnitude of seismic effects from the impact event and the subsequent collapse of the transient crater to form the final multi-ring structure are calculated. Second, new evidence for widespread seismicity in the Paraná Basin within a $1000 \mathrm{~km}$ radius of the impact site at the time of the Araguainha event is presented. Third, potential sources for the release of carbon from the impact event are discussed, followed by a summary of existing evidence for large-scale release of isotopically light carbon from the organic-rich rocks of the Passa Dois Group of the northern Paraná Basin. Finally, other proposed sources of disturbance to the Late Permian and Early Triassic carbon cycle are discussed and compared in terms of magnitude and expected duration relative to impactogenic methane release.

\section{Regional stratigraphy and geology of the Araguainha impact structure}

The Araguainha crater is located in the northern Paraná Basin, the western arm of an $\sim 3 \times 10^{6} \mathrm{~km}^{2}$ seaway linked during PermianTriassic times to the Karoo Basin of southern Africa (Milani and de Wit, 2007). The Paraná Basin in South America extends over roughly $1.5 \times 10^{6} \mathrm{~km}^{2}$, about three times the area covered by a modern-day analog, the Black Sea. The common stratigraphy for both the Paraná and Karoo basins (Gondwana Supersequence II) and the ubiquity of shallow marine fauna such as the Mesosaurids prove that these basins were connected prior to opening of the Atlantic Ocean (Milani and de Wit, 2007). The target rock stratigraphy of the northern Paraná Basin of Brazil was studied by Lana et al. $(2007,2008)$ from prominent exposures in the uplifted and folded sedimentary rocks that form the innermost collar and two concentric rings around the uplifted granite and impact melt at the core of the Araguainha impact structure. From bottom to top, the four major groups of sedimentary rocks that were affected by the impact event are the Silurian-Ordovician Ivaí Group (glacial diamictites and shales), the Devonian Paraná Group (red sandstone, siltstones, and arenose conglomerates), the Carboniferous-Permian Tubarão Group (basal conglomerates, sandstones, glacial diamictites), and the Middle to Late Permian Passa Dois Group (chert-rich carbonates, bituminous shales, and shales).

The Passa Dois Group comprises the youngest target rocks for the Araguainha bolide, and therefore provides the most tightly constrained maximum age for the impact. Volcanic ashes interbedded with the Irati Formation in the lowest part of the Pass Dois Group were dated at $278.4 \pm 2.2 \mathrm{Ma}$ by U-Pb SHRIMP analysis (Santos et al., 2006). The youngest target rocks belong to the Corumbataí Formation, which records a dual polarity (i.e., both normal and reversed directions), depositional remanent magnetization (Valencio et al., 1975). Therefore, deposition of the Corumbataí Formation post-dates the Kiaman Superchron, which ended at 262-268 Ma (Opdyke and Channell, 1996; Ogg et al., 2008; Lanci et al., 2013). In some regions, a distinctive stratigraphic unit, the Porongaba bed, forms a brecciated layer up to $5 \mathrm{~m}$ thick at the upper surface of the Corumbataí Formation (Matos and Coimbra, 1997; M. Schmieder pers. comm.). Unconformably overlying the Passa Dois Group are dunes of the Piramboia Formation, known as the Sanga do Cabral Formation in the southern reaches of the Paraná Basin. The Early Triassic age of these rocks is established by the presence of Lystrosaurus fossils (Milani et al., 2007).

Beyond the geochronological constraints on the age of the impact, the Passa Dois Group stratigraphy is significant for the large amounts of organic carbon sequestered in these rocks, particularly in the Iratí Formation. Deposited in the wake of the Artinskian deglaciation of Gondwana (Santos et al., 2006), a time period marked globally by massive burial of organic carbon (Berner, 2002), the mesosaurid-bearing black shales of the Iratí Formation record a transgressive marine sequence with $80 \mathrm{~m}$ of limestones, chert, and bituminous black shales underlain by massive dolomites. The Assistência Member of this formation is a $30-40 \mathrm{~m}$ thick unit that comprises $10 \mathrm{~cm}$-thick beds of intercalated bituminous shales and carbonates (Fig. 1). The high organic content renders this formation a commercially viable oil shale, exploited by Brazilian state oil company Petrobras. In South America, this oil shale horizon extends over 700,000 $\mathrm{km}^{2}$ (Araújo et al., 2000); together with the correlative Whitehill Formation of the Karoo Basin it constitutes one of the world's largest oil shale reservoirs (Dyni, 2006). The scale of these hydrocarbon deposits demonstrates a vast source of geologically sequestered light carbon.

Detailed stratigraphic and structural studies of the Araguainha peakring structure (Lana et al., 2007, 2008) document a central uplift with a $5 \mathrm{~km}$ diameter, with two sets of rings with radii of $10-12 \mathrm{~km}$ and 14-18 km, respectively, separated by annular basins. The central uplift is dominated by a shocked, Late Cambrian-aged granite basement ( $509.5 \pm 12.0 \mathrm{Ma}$ ) partly overlain by impact melt, and flanked by a polymict megabreccia with pseudotachylitic breccia veins. The impact melt was dated by U-Pb SHRIMP analysis of neoformed zircon and monazite, in addition to ${ }^{40} \mathrm{Ar} /{ }^{39} \mathrm{Ar}$ analysis of biotite and inclusions in post-impact quartz grains, yielding a mean-weighted age of $254.7 \pm$ 2.5 Ma (Tohver et al., 2012). The central uplift is collared by deformed sedimentary rocks of the overlying cover sequence, with upturned beds of the Devonian Furnas Formation sandstones forming prominent ridges. Based on the thickness of the Rio Ivaí, Paraná, and Passa Dois Groups, post-impact rebound of the excavated, transient crater exhumed ca. $2.5 \mathrm{~km}$ of sedimentary rocks around the central uplift. Postimpact crater modification resulted in thickening of these strata in the faulted and folded ring structures, with the magnitude of fault displacements decreasing outwards to a maximum of ca. $500 \mathrm{~m}$ along the outermost ring structure (Lana et al., 2007, 2008).

\section{Impact magnitude and seismicity}

\subsection{Calculated energy of Araguainha impact event}

The magnitude of the energy released by the impact can be inferred from the $40 \mathrm{~km}$ size of the crater, taking into account variables that include the angle of approach, the bolide velocity and composition (density), and the nature of the target material (Melosh, 1989). The impact modeling of Collins et al. (2005) was used to calculate the magnitude of energy released by the impact event. The model makes standard assumptions about impact angle ( $45^{\circ}$ was used); possible projectile compositions (iron or silicate for meteorites and ice for cometary bodies); and probable velocities ( $17 \mathrm{~km} / \mathrm{s}$ for Earth-crossing asteroid orbits and $50 \mathrm{~km} / \mathrm{s}$ for long period comet orbits); as well as the nature of the target material. These calculations show that the size the Araguainha structure is compatible with a 1-2 km diameter body into a water target, versus a 3-4 km body for unconsolidated sediments (loose sand), and would release ca.1-3 $\times 10^{5}$ Mt TNT equivalent upon impact with a water target or 2-6 $\times 10^{6}$ Mt TNT equivalent for an unconsolidated sand target. Given the shallow lagoonal facies of the Corumbataí Formation in the northern Paraná Basin, the energy released upon impact was probably somewhere in the middle of the calculated range, ca. $10^{6}$ Mt of TNT equivalent. 


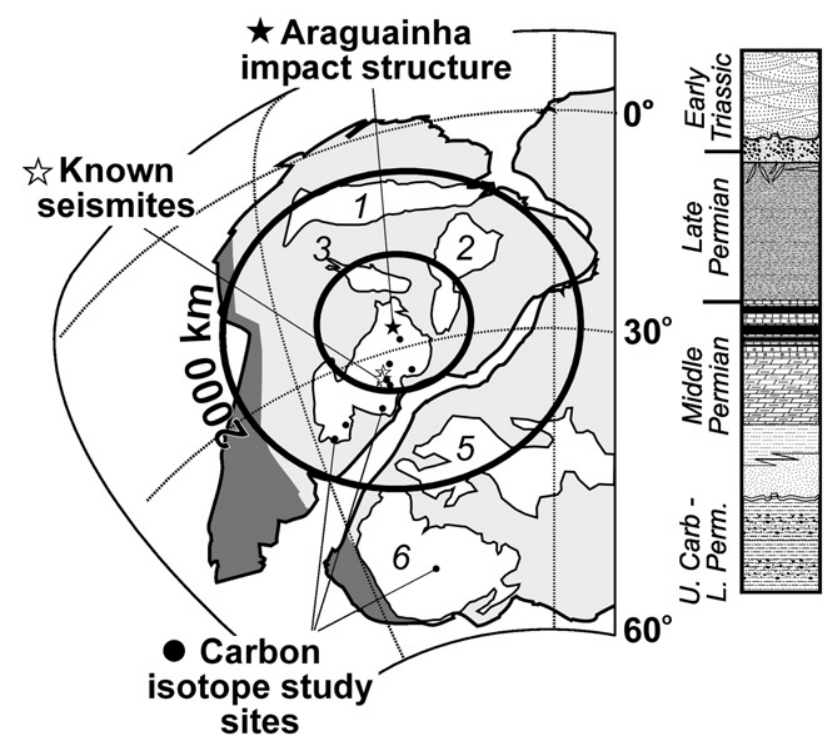

Piramboia Fm. (E. Triassic)

Aeolian dunes

Porongaba Bed

Corumbatai Fm. (<265 Ma)

breccias at upper contact,

sandstone, clastic dykes, basal

siltstone

Irati Fm (ca. $278 \mathrm{Ma}$ )

Assistencia Member- Oolitic

limestone, oil shale,

dolomite, siltstone

Rio Bonito Fm

Deltaic sandstone

unconformity

Tubarao Gp.

Coarse sandstone,

diamictite

Fig. 1. (L) Paleogeographic reconstruction of western Gondwana at the time of the Araguainha impact (black star), emphasizing the areal extent of interconnected shallow marine to intracontinental basins (1 - Amazonas-Solimões, 2 - Parnaíba-São Franciscana, 3 - Parecis, 4 - Paraná, 5 - Kalahari, 6 - Karoo), the known location of clastic dykes and outcrops of the Porongaba bed (white stars) and the sites of carbon isotope studies (black circles). Dark shaded region represents active margin of SW Gondwana. Concentric circles indicate distance from impact site in 1000 km increments. (R) Generalized stratigraphy of the northern Paraná Basin.

\subsection{Impactogenic seismicity}

The first seismic effects of the impact derive from the kinetic energy of the actual collision. However, only a small proportion of the kinetic energy of the bolide is converted into seismic motion, with the shockto-seismicity coefficient $\varepsilon_{\mathrm{e}}$ ranging from $10^{-2}$ for solid basalt to $10^{-4}$ for highly fractured material, respectively (Toon et al., 1997). The proximity of crystalline basement to the impact site signifies higher conversion of impact energy into seismic energy, but the seismic energy would also be attenuated by the sedimentary rocks of the Paraná Basin itself. Based on the range of both $\varepsilon_{\mathrm{e}}$ and the amount of energy released by the impact, the moment magnitude of impactogenic seismicity would range from 8.6 to 10.0 , with the true seismic effect of the impact likely to be near the middle of this range.

The second source of impactogenic seismicity is the post-impact collapse of the transient crater itself, creating the multi-ring structure observed today (Fig. 2). The friction-generating displacement of massive blocks along ring faults would generate considerable seismicity, and the magnitude of this seismicity can be calculated from the total area of the slip surface (Day an Maslin, 2005). Displacement along the ring faults was measured in the field using the stratigraphy of the Paraná Basin sediments (Lana et al., 2007, 2008), with 500 m of offset observed along the $20 \mathrm{~km}$ radius outer rim of the crater, ca. $1500 \mathrm{~m}$ offset along the $12 \mathrm{~km}$ radius interior ring, and at least $2500 \mathrm{~m}$ offset along the $2.5 \mathrm{~km}$ radius central uplift where the Araguainha granite basement denuded the entire sedimentary overburden. These dimensions yield a total displaced area of $2 \times 10^{2} \mathrm{~km}^{2}$ for a simple cylindrical model of the fault geometry, where the displacement is equivalent to the height of the cylinder. For comparison, the 2004 Andaman-Sumatran earthquake $\left(\mathrm{M}_{\mathrm{w}} 9.0-9.3\right)$ was marked by $15 \mathrm{~m}$ displacement along a $1600 \mathrm{~km}$ long fault section, an area equivalent to ca. $24 \mathrm{~km}^{2}$ (Lay et al., 2005). A more realistic conical geometry for the ring faults accounts for faults that sole into listric, low angle structures at depth (Spray, 1997). In this case, the total amount of displacement indicates the height of the cone, and the total equivalent area of displacement is equivalent to $3.5 \times 10^{3} \mathrm{~km}^{2}$. The total moment magnitude from motion along these faults ranges from 9.2 to 9.5 (Day and Maslin, 2005).

The total seismic effects from both the impact and the collapse of the transient crater are equivalent to a 9.3-10.1 magnitude earthquake, similar to, or up to an order of magnitude larger than the largest tectonic earthquakes. Empirical observations of landslides caused by earthquakes by Keefer (1984) suggest a relationship between the timeintegrated intensity of ground shaking (acceleration squared) and the severity and distribution of mechanical failure of various sediment types. Using the technique outlined by Keefer (1984) and Wilson and Keefer (1985), the seismic moment magnitude can be converted to Arias intensity and used to predict the distance over which groundshaking will exceed the shear strength of the target material $(0.2 \mathrm{~m} / \mathrm{s}$ for water-saturated, unconsolidated sediments). Thus, the summed seismic effects of the Araguainha crater could provoke landslides within a $700-3600 \mathrm{~km}$ radius of the impact site (Fig. 3). This is in keeping with the observed $900 \mathrm{~km}$ radius of landslides for the 1755 Lisbon earthquake, or the $7000 \mathrm{~km}$ radius of slope failure for the Chicxulub impact (Day and Maslin, 2005). In the following discussion, the calculated size for the "ring of destruction" constrains the search for geological evidence of ground shaking. Secondary effects of the impact wrought by ejecta and tsunamis could affect a still larger area.

\subsection{Observations of impactogenic seismicity}

The stratigraphic record of the Paraná Basin contains clear evidence for environmental changes from end Permian to Early Triassic time, with the sedimentary environment switching from saline lagoons (uppermost Corumbataí Formation) to the aeolian dunes of the Early Triassic Piramboia Formation (Assine et al., 2004). This secular transition has been ascribed to a global sea level fall (e.g., Hallam, 1992) with the regional emergence of dry land in the interior of Gondwana during the early Mesozoic. However, evidence for an abrupt, singular event within the northern and central Paraná Basin can be found at the contact between the uppermost Passa Dois Group and the overlying Piramboia Formation. The nature of this contact varies with increasing distance from the Araguainha structure, the point source for impactogenic seismicity. In the vicinity of the crater, the Piramboia Formation is absent (Lana et al., 2007), probably reflecting the positive relief of the multi-ring Araguainha structure.

At distances of $800-1000 \mathrm{~km}$ from the crater, evidence for widespread seismicity in the Permian-Triassic interval is found in the Porongaba bed, which is observed only at the contact between the late Paleozoic and early Mesozoic sedimentary sequences (Matos and 


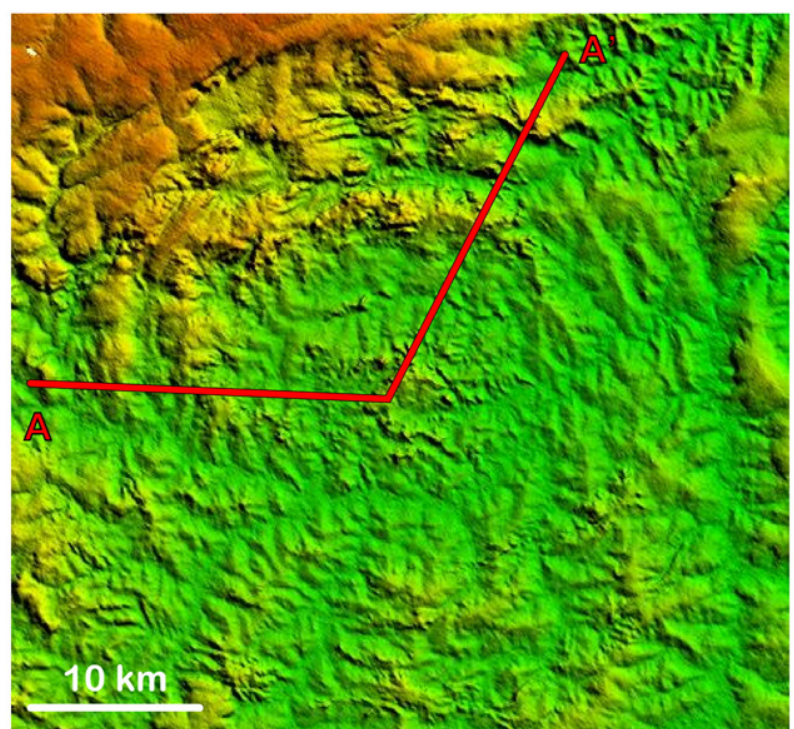

A
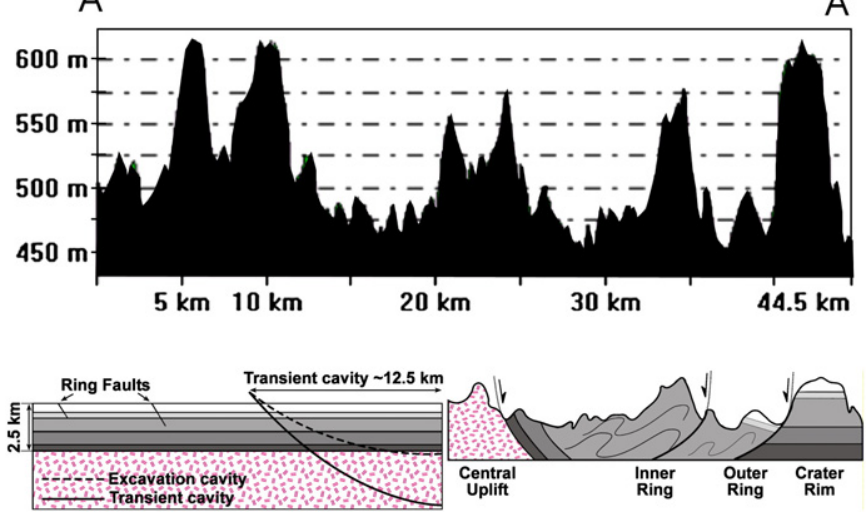

Fig. 2. (Top) Colored, shaded relief digital elevation model of the Araguainha impact crater, with the $\mathrm{A}-\mathrm{A}^{\prime}$ cross-section (Middle) demonstrating the modern topographical signature of the two concentric rings and the uplifted core of the crater. The preserved topography of the multi-ring structure demonstrates the significant motion along fault zones during the centripetal collapse of the transient crater in the immediate aftermath of the impact. (Bottom) Schematic geology of the Araguainha target rocks before (left) and after postimpact crater modification (right) shows the ring faults and displaced stratigraphy of the modern impact structure.

Coimbra, 1997; unpub. data. M. Schmieder). This bed is characterized by a matrix- or clast-supported breccia that ranges in thickness from 0.5 to $4.5 \mathrm{~m}$, with angulose clasts diminishing in size up through the thickness of the bed, grading into a unbedded sandstone (Almeida, 1964) The clasts consist of siltstones, sandstone, cherts, and carbonates derived from various facies of the Passa Dois Group (Almeida, 1964; Matos and Coimbra, 1997). Thus, the breccia is not restricted to, nor diagnostic of any depositional environment. The clast fabric within the Porongaba bed is weakly oriented to chaotic; in some localities, the angulose clasts of the brecciated bed have been re-oriented by strong water currents (Matos and Coimbra, 1997), but we have also observed fitted clasts that indicate minimal reworking after brecciation. Matos and Coimbra (1997) describe lateral gradations of the Porongaba bed into moderately fractured or even undisturbed beds. The upper contact with the Piramboia Formation is abrupt and planar, contrary to features in breccias caused by dissolution of evaporite horizons. No paleosols are observed, nor is there any other evidence of significant subaerial exposures, dessication horizons, or possible fault-related genesis for the breccia bed.

Some of the features of the Porongaba Bed are consistent with an autoclastic breccia created during seismic shaking by the contrasting rheological response of intercalations of brittle and viscous horizons

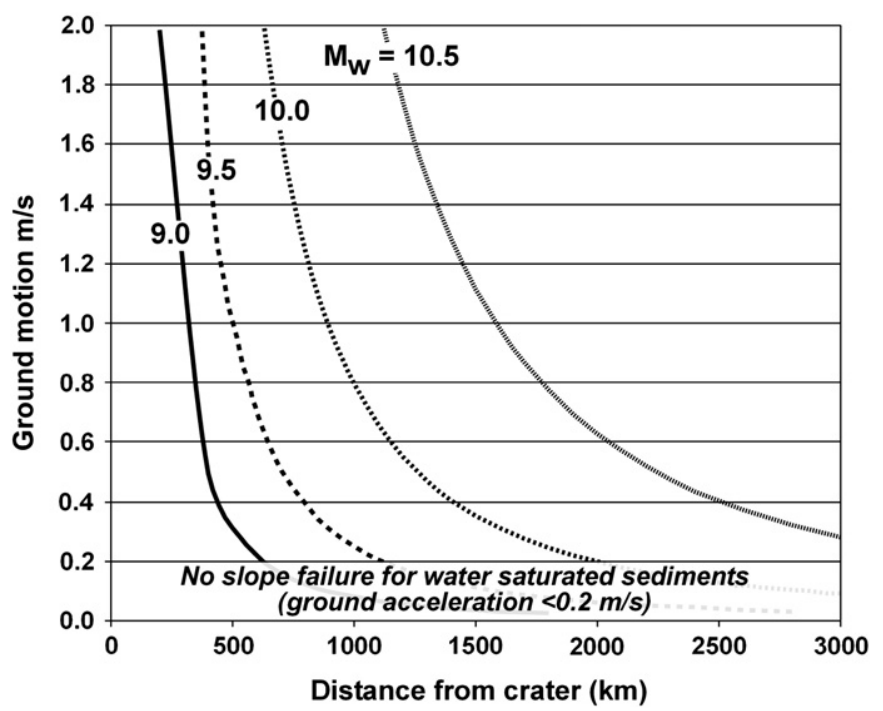

Fig. 3. Calculated radii for the landslide-prone ring of destruction according to various estimates of the seismic effects of the Araguainha impact event and subsequent collapse of the transient crater.

(Montenat et al., 2006). However, the diversity of clast lithologies suggests another origin for the Porongaba bed as a "water blow breccia" such as that described by Lindström et al. $(p .43,2008)$ in the vicinity of the Lockne structure. These deposits reflect sediment excavation and deposition by a radially propagating, sediment-saturated surge deposit caused by a bolide impact into a shallow water environment. Similar sedimentary facies were described by Witzke and Anderson (1996) associated with the Manson crater of the central U.S.A., who described the action of a "ground-hugging debris surge" (p. 119). An additional factor for the subaqueous deposits would have been traction developed during eventual resurgence of water in the aqueous equivalent of crater collapse.

Additional evidence for seismicity at the time of the Araguainha impact is presented by swarms of hundreds of individual clastic dykes within the thinly bedded units of the Corumbataí Formation (Turra, 2009), observed at three localities ranging from 800 to $1200 \mathrm{~km}$ distance from the Araguainha crater (Fig. 4 (left)). These dykes were created by the forceful, upward injection of water-saturated sand into the overlying mudstones by seismic liquefaction (Surlyk et al., 2007; Turra, 2009). The timing of this seismicity is constrained to PermianTriassic times, as the dykes cross-cut only latest Permian sediments but not the overlying Triassic rocks (Riccomini et al., 2005). These same authors speculated about the possible episodic nature of this seismicity, given that at least three separate stratigraphic horizons within the Corumbataí Formation are affected, although this might reflect a single event affecting three separate, thixotropic horizons. The map pattern of dykes indicates a NNW-NNE orientation approximately radial to the impact epicenter. The dykes range in thickness from 5 to $25 \mathrm{~cm}$ (Fig. 4 (right)), with many dykes demonstrating a post-emplacement vertical shortening that signifies compaction of unlithified sediments. Tectonic seismicity is unlikely in the region, because the nearest active plate boundary was approximately $2000 \mathrm{~km}$ away, so these dykes are interpreted as the result of impactogenic seismicity.

In the central portion of the Paraná Basin, at distances of $1000-1500 \mathrm{~km}$ from the impact, the contact between the Passa Dois Group and Piramboia Formation is more gradational (Riccomini et al., 1992). Here, the uppermost Corumbataí Formation hosts thick sandstone bodies interpreted as tempestites, and the lowermost Piramboia Formation is characterized by the development of chaotic, intraformational folds, sand injections, and tubular structures interpreted as the results of sediment liquefaction (Chamani et al., 1992) or as dewatering structures by Fernandes and Coimbra (1993). The inferred 

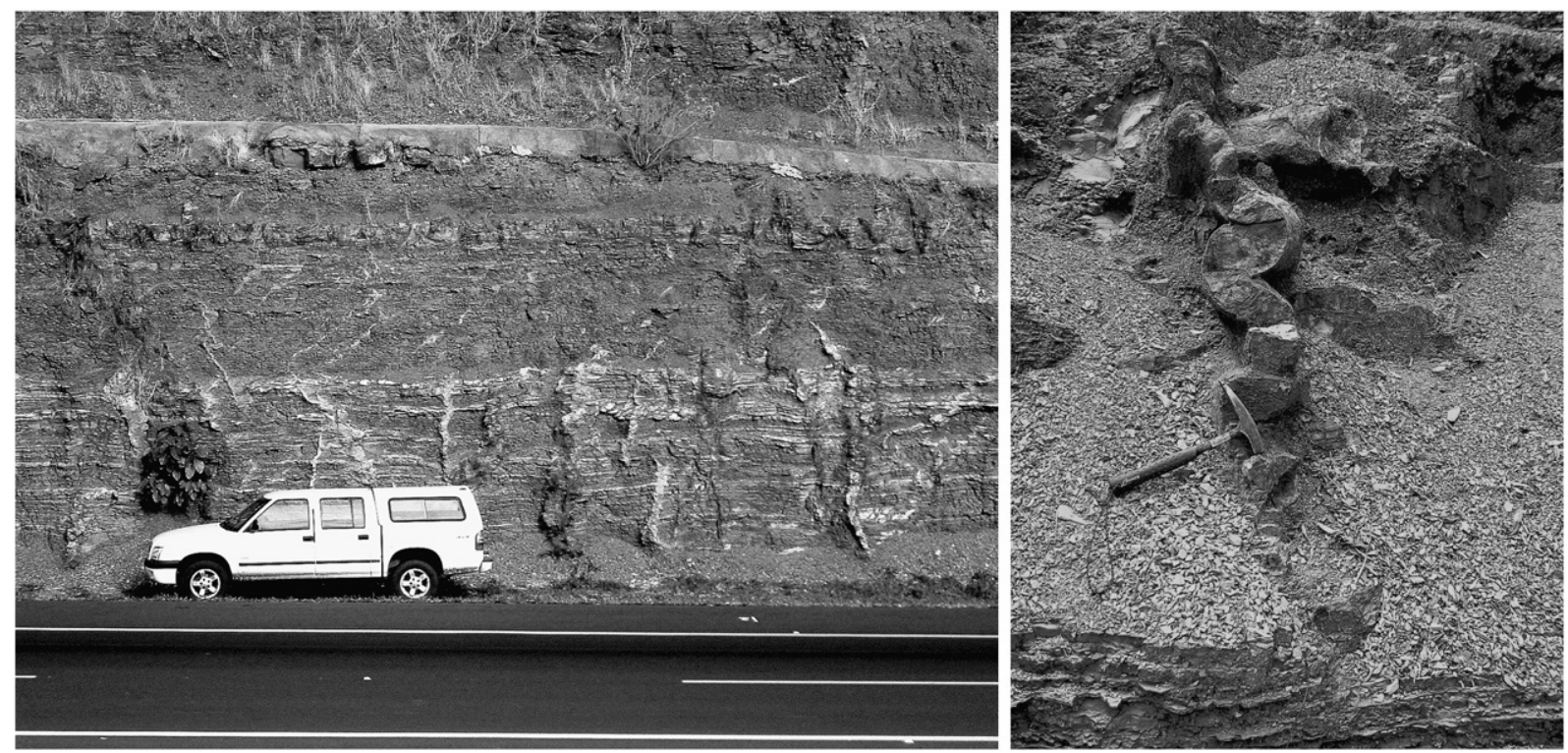

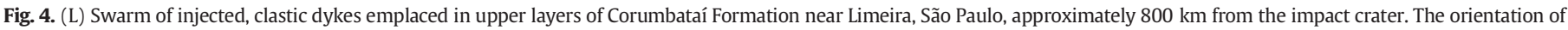
observed dykes is roughly radial to the impact site. $(\mathrm{R})$ Vertical compaction of the dyke indicates the unlithified nature of the sediments at the time of dyke formation.

water depths at the center of the basin are at odds with thick sand bodies, and are suggestive of strong, subaqueous currents consistent with tsunami deposits.

\section{Discussion}

The link between the Araguainha impact seismicity and the global carbon cycle lies in the unusual, hydrocarbon-rich rocks of the Paraná Basin. First, the sources and size of the carbon input need to be identified and quantified.

\subsection{Potential sources of carbon release from an impact event}

Carbon from the Araguainha impact would have been liberated from three sources, volatilization of the bolide itself, volatilization of the target rocks, and methane released by impactogenic seismicity. The magnitude of the first source can be estimated from a simple volumetric calculation of the amount of carbon likely to be present in meteorites of various bulk compositions and assuming chondritic values for the isotopic composition of carbon in the body. Our previous calculations of the probable size of the bolide indicate that Araguainha crater is consistent with a $2-3 \mathrm{~km}$ diameter stony meteorite with $3-5 \%$ carbon (Kerridge, 1985 ) yielding $1-5 \mathrm{Gt}$ of carbon with $\delta^{13} \mathrm{C}_{\mathrm{PDB}}=-10 \%$, or a $2-5 \mathrm{~km}$ comet containing 25\% C with $\delta^{13} \mathrm{C}_{\mathrm{PDB}}=-45 \%$ (Messenger, 2000), which could contribute 3-80 Gt of carbon. The second source of carbon release is the evaporated target rocks, notably, the organic- $\mathrm{C}$ rich rocks of the Iratí Formation with $\delta^{13} \mathrm{C}_{\mathrm{PDB}}$ values that range from -20 to $-24 \%$ (Faure and Cole, 1999). A cylindrical approximation of the $40 \mathrm{~m}$ thick Assistência Member within the 10-12 km radius transient cavity contains ca. $25 \mathrm{Gt}$ of carbon. Since not all of the rock material in the transient cavity is vaporized, some material having been either ejected from the crater or incorporated into the ring structure, this $25 \mathrm{Gt}$ figure is probably a maximum value.

The third source of carbon, methane released from the sediment column as a result of impactogenic seismicity, is the largest volumetrically and presents the greatest potential for perturbation of the carbon isotope record. The Iratí Formation contains a large reservoir of organic carbon, the Assistencia Member. Methane from the Iratí Formation would exist as either a free gas in pore space in the sediment column, or as a solid $\mathrm{CH}_{4}$ clathrate in a zone bounded at the top by the sediment-water interface and at the bottom by the intersection of the local geothermal gradient and the clathrate-water equilibrium curve. The chemical phase of methane in the sediment column depends on intrinsic variables for the methane- $\mathrm{H}_{2} \mathrm{O}$ phase diagram: temperature, (water) pressure, gas concentration, and water salinity (Buffett, 2006). The dominant geological factor is the water depth of the ParanáKaroo Basin, with methane clathrates stable in the sediment column at water depths greater than ca. $300 \mathrm{~m}$ for high latitude marine sites, and in subtropical marine waters at depths greater than ca. $600 \mathrm{~m}$ (Macleod, 1982). For example, the ca. $30^{\circ}$ paleolatitude of the Paraná Basin in Permian-Triassic times would require an intermediate water depth (ca. $450 \mathrm{~m}$ ) for the stability of methane clathrate, whereas the brackish water of the Paraná Basin would favor the stability of methane clathrate (Dickens and Quinby-Hunt, 1997). The presence of methane clathrate in the Paraná Basin is an important, open question, though possibly moot, because the low permeability of the overlying mudstones of the Corumbataí Formation would serve as a stratigraphic trap for even gaseous methane before the Araguainha impact event.

The stratigraphic record of impacts includes slumping and liquefaction of unconsolidated sediments (e.g., Soria et al., 2001; Simms, 2003). Conventional tectonic earthquakes are known to cause turbidity currents by slope failure, causing sediment liquefaction and removing the overburden from pressure-sensitive methane clathrates (Rothwell et al., 1998; Katz et al., 1999). The resultant release of gaseous methane from disturbed subaqueous sediments presents an enormous potential source of isotopically light carbon as well as a potent greenhouse gas. The subdued slope of the Paraná and Parnaíba basins relative to the continental rise of marine basins dictates some modifications to the continental slope failure model. In view of this, we assume a conservative cross-sectional area of $3 \mathrm{~km}^{2}$ per $\mathrm{km}$ of margin was liable to slope failure, versus the $35 \mathrm{~km}^{2}$ per $\mathrm{km}$ used for standard continental margin (Dickens, 2001). Likewise, we assume $10 \%$ of available pore space in basin sediments was filled with methane in the solid clathrate form. The previously determined $700-3600 \mathrm{~km}$ radius of slump-inducing seismic shaking provides boundary conditions for our search for evidence of methane release. Given the perimeter of the basins within the seismic range of the impact (Fig. 1), the range in magnitude of seismic effects indicates the potential release of 600 to $3000 \mathrm{Gt}$ of methane. This estimate will be revisited in the Discussion section with mass balance calculations for isotopic fractionation of methane inferred from the disturbed $\mathrm{C}$-isotope values of the Assistência Member. 


\subsection{Geological evidence for methane release in the Paraná Basin}

Normally, the carbon isotope value of primary carbonate minerals precipitated inorganically in equilibrium with seawater will reflect the isotopic values of dissolved $\mathrm{C}$ in the form of $\mathrm{CO}_{2}^{-2}$ or $\mathrm{HCO}_{3}^{-}$. Recent compilations of carbon isotopes (Veizer et al., 1999) suggest a global average of $+4 \delta^{13} \mathrm{C}$ for Artinskian seawater, the time of the deposition of the Irati Formation. It is expected that the high organic content of the Irati Formation will affect the isotopic values of the bulk rock carbon reservoir, assuming closed system behavior. Indeed, the correlation between total organic carbon content and negative isotopic $\delta^{13} \mathrm{C}$ values in the carbonate matrix was confirmed by Rodrigues et al. (2010) for samples of the Iratí Formation in the southern Paraná Basin, ca.1200 km from the Araguainha impact. A final consideration is the fermenting role of bacteria in the breakdown of organic material and the resultant $75 \%$ 。 fractionation of isotopically light $\mathrm{CH}_{4}$ from $\mathrm{CO}_{2}$, a process that leads to the formation of heavy carbonates with highly positive $\delta^{13} \mathrm{C}$ of up to $+15 \%$ o in residual carbonate (Irwin et al., 1977; Whiticar, 1999). Methane released by this process would reside in pore water at low pressure/high temperature, or form methane clathrate under high pressure/low temperature conditions (Macleod, 1982).

A review of the available inorganic carbon isotope data from the Paraná Basin reveals a wide range of values that correspond to distance from the Araguainha impact site (Fig. 5a). In an early study of the Iratí Formation, de Giovani et al. (1974) identified a pattern of highly positive values for the thinly bedded limestone $\left(\delta^{13} \mathrm{C}\right.$ values of +10 to $+20 \%$ ) and more moderate values of $-7 \%$ to $+2 \%$ for the underlying massive dolostones. The highly positive $\delta^{13} \mathrm{C}$ values are caused by the post-diagenetic dissociation of methane, given its great mobility and extreme enrichment in ${ }^{12} \mathrm{C}$, leaving the residual inorganic carbonate enriched in ${ }^{13} \mathrm{C}$ (de Giovani et al., 1974). At the basin scale, the evidence for this methane dissociation pattern is marked by predominantly ${ }^{13} \mathrm{C}$-rich carbonates (mean-weighted $\delta^{13} \mathrm{C}$ of +5 ) within $1000 \mathrm{~km}$ of the Araguainha impact site (Fig. 5a), with the "heavy" carbonates not found outside a $1500 \mathrm{~km}$ radius of the impact site. This pattern is demonstrably not a thermal effect of the Cretaceous emplacement of the Paraná flood basalts and associated mafic intrusives, which are found uniformly throughout the basin. For example, at a site $120 \mathrm{~km}$ from the Araguainha impact site, Santos et al. (2009) demonstrate extreme depletion in light carbon for thinly-bedded limestones $\left(\delta^{13} \mathrm{C}+8\right.$ $12 \%$ ). Isotopic effects from the intrusion of a $13 \mathrm{~m}$ thick Cretaceous sill are restricted to a 2-4 $\mathrm{m}$ thick thermal halo above and below the sill where $\delta^{13} \mathrm{C}$ values were less positive, closer to 0 .

Evidence for methane loss from carbonates within the oil shale horizon diminishes at distances greater than $1000 \mathrm{~km}$ from the Araguainha impact site. Rodrigues et al. (2010) reported negative $\delta^{13} \mathrm{C}$ values from organic-rich carbonates of the Iratí Formation, replicating the results of de Giovani et al. (1974) who credited primary carbon isotope values to sites located ca. $1400 \mathrm{~km}$ distance from the crater, in the southernmost portion of the Paraná Basin. Similarly, in their study of the organic-rich Whitehill Formation of the Karoo Basin, Faure and Cole (1999) report chiefly negative $\delta^{13} \mathrm{C}$ values for inorganic carbonates.

A similar pattern consistent with methane loss can also be seen in the variation of organic $C$ isotopic values, with the heaviest $\delta^{13} \mathrm{C}$ values (mean-weighted value of -24 ) found at distances $500-1000 \mathrm{~km}$ from the crater, and increasingly light values at distances of ca. $1500 \mathrm{~km}$ (Fig. 5b). This variation is larger than what would be expected for the ca. $10^{\circ}$ of paleolatitudinal distance between sample sites in the subtropical to low temperate zone occupied by the Permian-Triassic Paraná Basin. In modern ocean waters, this zone is marked by low variation in the ${ }^{13} \mathrm{C}$ of organic $\mathrm{C}$, with the effect of temperature on $\mathrm{C}$ fractionation becoming evident at latitudes $>45^{\circ}$ (Goericke and Fry, 1994; Andrusevich et al., 2000). Further evidence of the postdiagenetic decoupling of carbon between the organic and carbonate reservoir in the Paraná Basin is observed in the variation of $\varepsilon_{\mathrm{TOC}}$ values $\left(\delta^{13} C_{\text {carbonate }}-\delta^{13} C_{\text {organic }}\right.$ ) for paired samples (Fig. $5 c$ ) reported by Araújo
(2000). According to Hayes et al. (1999), the isotopic fractionation of carbon between organic material and inorganic carbonate should be constant for a given phytoplankton assemblage under uniform $\mathrm{pCO}_{2}$ and temperature conditions. Thus, the observed departure from constant $\varepsilon_{\mathrm{TO}}$ in the Paraná Basin reflects secondary, post-diagenetic effects that are consistent with methane loss in the ca. $1000 \mathrm{~km}$ vicinity of the Araguainha impact site.

\subsection{Magnitude of impactogenic methane release}

Evidence from the Paraná-Karoo Basin points to widespread seismicity at the time of the Araguainha impact. Clearly documented seismites, soft-sediment deformation, and possible tsunami deposits are found within $1200 \mathrm{~km}$ of the impact crater and are stratigraphically constrained to have occurred at the time of the Araguainha impact. Registers of seismicity within the central Paraná Basin are located at least $2000 \mathrm{~km}$ from the nearest Permian-Triassic plate boundary, and are thus unlikely to be the result of conventional tectonic earthquakes. Existing carbon isotope data also indicate the widespread occurrence of methane release within the northern portion of the Paraná Basin, although the timing of this methane release is difficult to establish directly. Mass balance calculations can be used to estimate the amount of methane fractionation required to generate highly positive $\delta^{13} \mathrm{C}$ values from the thinly-bedded carbonates of the Iratí Formation. The fractionation of methane during bacterial fermentation processes is described by Irwin et al. (1977). At distances of ca. $1500 \mathrm{~km}$ from the impact, the measured values in massive dolomites and interbedded black shales and carbonates of the Iratí Formation demonstrate isotopic reequilibration of carbon during diagenesis, i.e., generally negative $\delta^{13} \mathrm{C}$ values. Given a total organic content for the Iratí Formation of $35 \%$, and $\delta^{13} \mathrm{C}_{\text {carb }}$ and $\delta^{13} \mathrm{C}_{\text {org }}$ values of $+4 \%$ and $-20 \%$, respectively, we calculate a bulk isotopic value of roughly $-6 \%$. In order to generate the $+15 \%$ s signatures found in the inorganic carbonates, mass balance indicates that $30 \%$ of the original carbon reservoir could have been incorporated into $\mathrm{CH}_{4}$. Loss of methane appears to affect an area within a minimum distance of $\sim 1100 \mathrm{~km}$ radius from the crater, the area in seismic activity and heavy Iratí Formation carbonates are both observed. This equates to $\sim 60 \%$ of the Paraná Basin, or roughly $1 \times 10^{6} \mathrm{~km}^{2}$. Restricting methane loss to the upper $20 \mathrm{~m}$ of thinly bedded, carbonate-black shale horizons (TOC 30\%) of the Assistência Member of the Iratí Formation, and the 0.9 tons $/ \mathrm{m}^{3}$ density of methane clathrate, the mass of methane release is calculated to be ca. $1600 \mathrm{Gt}$. This value is in the middle of the less constrained 600-3000 Gigaton range previously suggested by the generic liquefaction-slope failure model.

\subsection{Implications for the Permian-Triassic carbon isotope record}

The record of carbon isotope excursions in the Late Permian and Early Triassic is marked by a smooth, long wavelength decrease in $\delta^{13} \mathrm{C}$ that predates the mass extinction horizon (Xie et al., 2007; Cao et al., 2009) and continues into the Early Triassic (Payne et al., 2004; Payne and Kump, 2007). This relatively smooth decrease is marked by dramatic fluctuations at the mass extinction horizon itself, where a sharp 3-5\% drop (Jin et al., 2000) is observed, with recovery followed by a second decrease (Xie et al., 2007; Korte and Kozur, 2010). Using high precision U-Pb TIMS dating of volcanic zircon in ashbeds above and below the mass extinction horizon, Shen et al. (2011) calculated a duration for this first excursion of $<20 \mathrm{ka}$. Multiple excursions continuing through the Early Triassic could also reflect similarly short timescales.

The close timing of the carbon isotope excursions and the PermianTriassic mass extinction raises the question of how these two phenomena are related. The most direct link conceivable would be if the shift was due to carbon release from oxidation of dead biomass such as in the Strangelove ocean hypothesis (Hsü and McKenzie, 1990), with 
a 25

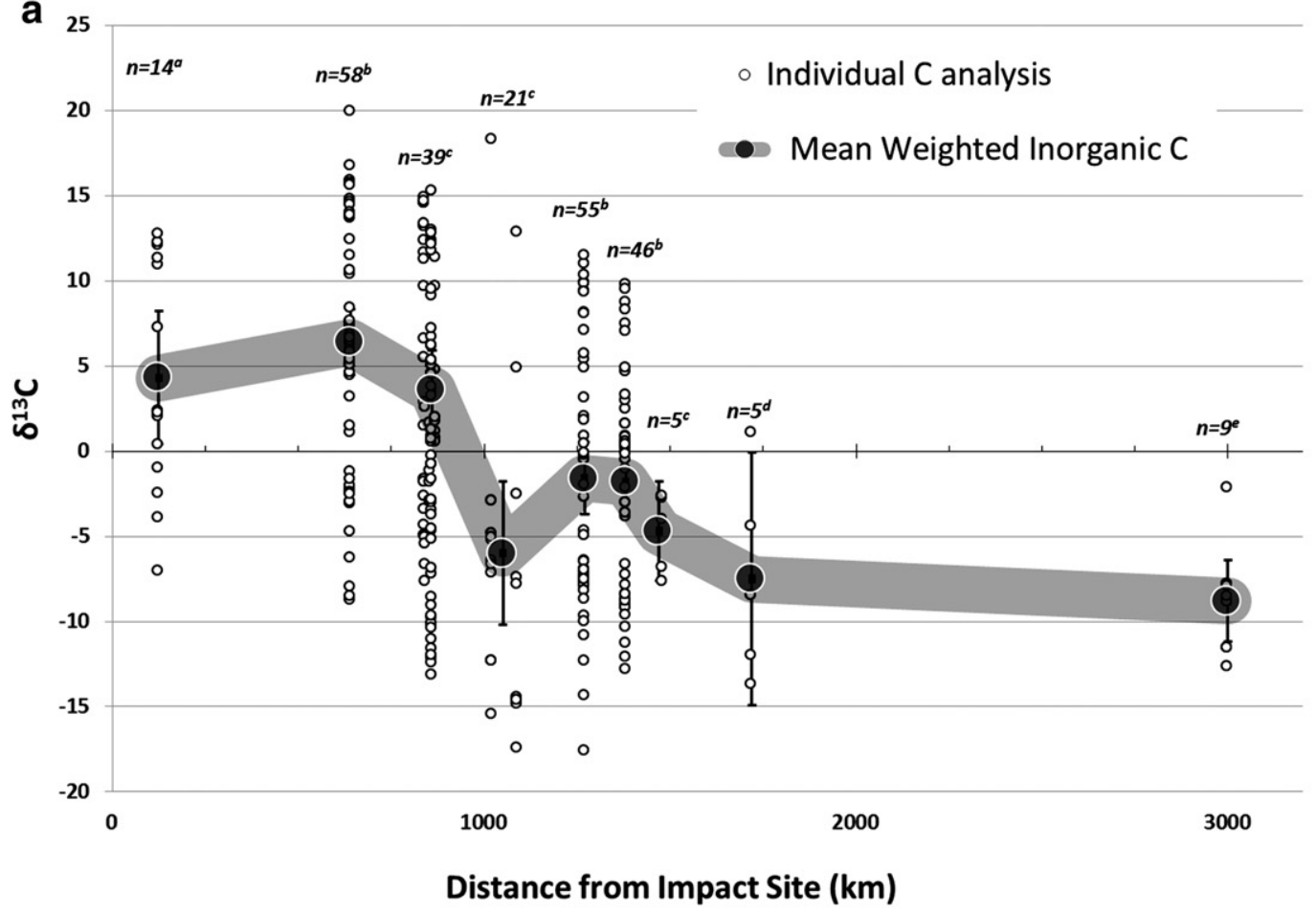

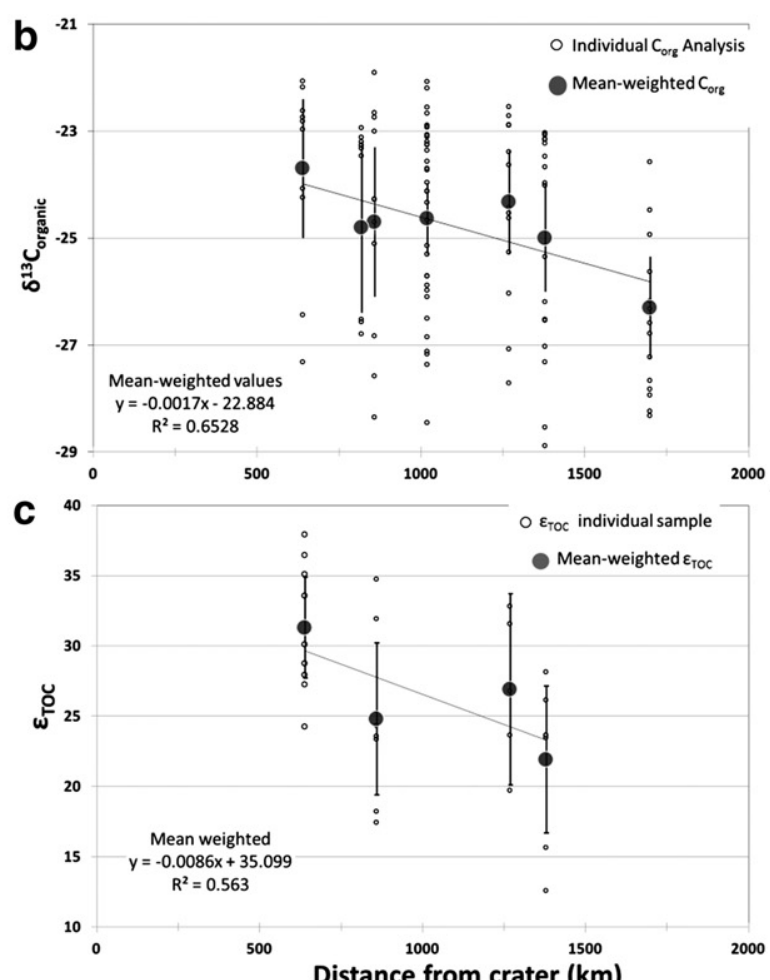

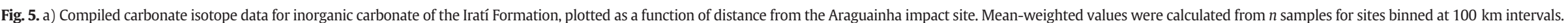

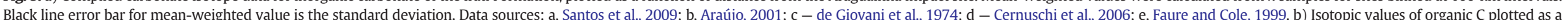

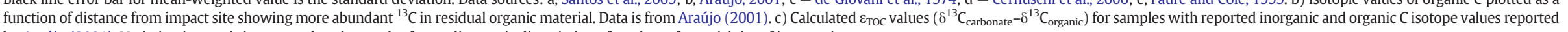
by Araújo (2001). Variation in $\varepsilon_{\mathrm{T} O c}$ is interpreted as the result of post-diagenetic dissociation of methane from vicinity of impact site. 
more sustained and significant isotopic shifts caused by the suppression of primary productivity and low burial rates of organic carbon (Kump, 1991). Many of the proposed kill mechanisms are explicitly linked to the carbon isotope record: massive volcanic outgassing of mantle $\mathrm{CO}_{2}$ (Renne and Basu, 1991; Renne et al., 1995); the devolatilization of coal, organic-rich shales, and evaporites in the Tunguska basin country rocks during emplacement of the Permian-Triassic Siberian traps (Retallack and Jahren, 2008; Ganino and Arndt, 2009; Svensen et al., 2009; Korte et al., 2010; Aarnes et al., 2011) or degassing of the plume head itself (Sobolev et al., 2011); the development of anoxic ocean waters leading to convective overturn of a stratified ocean (Knoll et al., 1996) or direct degassing of $\mathrm{CH}_{4}$ and $\mathrm{CO}_{2}$ from decomposing organic material in euxinic waters (Isozaki, 1997; Ryskin, 2003; Grice et al., 2005; Kump et al., 2005; Algeo et al., 2008; Kump); or massive release of methane (Erwin, 1993; Bowring et al., 1998; Krull and Retallack, 2000; Retallack and Krull, 2006), possibly caused by warming of ocean waters and destabilization of methane clathrate (Berner, 2002).

The smooth decline of carbon isotope values from the Late Permian and continuing into the Early Triassic is adequately explained by Siberian Traps magmatism (Svensen et al., 2009; Korte and Kozur 2010). Modeling of the thermal effects of basaltic intrusions into sediments by Aarnes et al. $(2010,2011)$ indicates the predominance of degassing of $\mathrm{CH}_{4}$ (and $\mathrm{H}_{2} \mathrm{O}$ ) from shales over coals, which tend to decompose to $\mathrm{CO}_{2}$, given the lower order kerogen present in coal. These modeling studies demonstrate the largest potential for release of $\mathrm{CH}_{4}$ from devolatilization of shales with TOC $>5 \%(12,000-66,000 \mathrm{Gt}$; Aarnes et al., 2011). Although the magnitude of degassing on this scale is clearly sufficient to measurably disturb the carbon isotope record, the duration of metamorphic devolatilization is more problematic. Given the thermal diffusivity of shale, the amount of time necessary for $100 \%$ devolatilization reactions is on the order of $10-50 \mathrm{ka}$, with $\sim 50 \%$ of gases produced in approximately one-tenth the time (Aarnes et al., 2011). In terms of the exhalation of gases at the surface, these calculated times probably represent minimum values, given the time necessary for magma emplacement, assumed to be instantaneous in the models, and the depth-dependent time for passage of subterranean gases through the rock column to the surface. Given the $10^{6}$ year timescale for the development of large igneous provinces such as the Siberian traps (Renne and Basu, 1991; Renne et al., 1995; Reichow et al., 2009; Saunders and Reichow, 2009), it is reasonable to impute the isotopic effects to a similar $10^{6}$ Ma period of time, probably accounting for the smooth drift to lower ${ }^{13} \mathrm{C}$ values for $500 \mathrm{ka}$ preceding the mass extinction horizon and continuing into the Early Triassic (Payne et al., 2004; Payne and Kump, 2007).

of the proposed mechanisms, methane release is distinguished by its rapid and substantial effect on $\delta^{13} \mathrm{C}$ of seawater, given the extremely light values that characterize biogenic methane $(-60 \%$ o versus $-35 \%$ for thermogenic methane from contact metamorphism of organic-rich shales, or mantle-derived volcanic $\mathrm{CO}_{2}\left(-6 \%\right.$ ), or $\mathrm{CO}_{2}$ from metamorphic combustion of coal ( -2 to $0 \%$ ). The 10 year timescale for oxidation of methane provides an instantaneous source of isotopically light, atmospheric carbon dioxide (Berner, 2002). Mass balance calculations for the negative 2-3\% shift in carbon isotopes at the Paleocene-Eocene transition suggest that 1000-3000 Gt biogenic $\mathrm{CH}_{4}$ is required (Dickens et al., 1995), which drops by a factor of 4-5 if the reservoir is restricted to the atmosphere and surface ocean carbon reservoirs (Kent et al., 2003). The extremely short duration of the isotopic excursion at the mass extinction horizon event $(<20 \mathrm{ka})$ is more consistent with the timescale of methane release from an impact event, where timescales for methane release from impactogenic earthquakes and tsunamis would be on order of minutes to days. The ca. $10^{3} \mathrm{Gt}$ of methane calculated to have been released from the seismically-disturbed sediments of the Paraná Basin could account for some of this sharp isotopic shift, superimposed on the more gradual decline caused by metamorphic devolatilization associated with Siberian traps magmatism.

\section{Conclusions}

Geological evidence for seismic and carbon isotope perturbation in the northern Paraná Basin suggests that the Araguainha impact event affected areas up to $1100 \mathrm{~km}$ distant from the crater. Mass balance calculations indicate that approximately $1600 \mathrm{Gt}$ of methane were liberated by impactogenic seismicity, whereas a more generalized slope failure model suggests a range of 600-3000 Gt of methane release. These observations confirm the viability of large-scale methane release by a mid-sized impact event, given organic $\mathrm{C}$-rich target rocks. Massive release of methane at this scale would have immediate consequences for the biosphere, with climate perturbation effected by a rapid spike in greenhouse gases. Given the established Permian-Triassic age of the Araguainha crater, it is proposed that this methane release was responsible for some of the observed isotopic shift at the Permian-Triassic boundary. The rapid isotopic shift would be distinguished from the more gradual $10^{5}-10^{6}$ year shift caused by outgassing of the Siberian Traps and devolatilization of mature organic material in country rocks. The cascading effects of the impact represent a possible, large-scale perturbation to the Earth's carbon budget, suggesting that the carbon isotope shift may not be related to primary productivity during the mass extinction.

\section{Acknowledgments}

This study was carried out with the support from the Australian Research Council (LP0991834 and DP110104818), the University of Western Australia, the Fundação de Ámparo á Pesquisa do Estado de São Paulo (FAPESP), and the Fundação de Ámparo á Pesquisa do Estado de Minas Gerais (FAPESP; APQ-00870-11). The editorial advice of F. Surlyk and two anonymous reviewers is greatly appreciated.

\section{References}

Aarnes, I., Svensen, H., Connolly, J.A.D., Podladchikov, Y.Y., 2010. How contact metamorphism can trigger global climate changes: modeling gas generation around igneous sills in sedimentary basins. Geochimica et Cosmochimica Acta 74, 7179-7195.

Aarnes, I., Fristad, K., Planke, S., Svensen, H., 2011. The impact of host rock composition on devolatilization of sedimentary rocks during contact metamorphism around mafic sheet intrusions. Geochemistry, Geophysics, Geosystems 12, Q10019.

Algeo, T., Shen, Yanan, Zhang, Tonggang, Lyons, T., Bates, S., Rowe, H., Nguyen, T.K.T., 2008. Association of ${ }^{34} \mathrm{~S}$-depleted pyrite layers with negative carbonate $\mathrm{d}^{13} \mathrm{C}$ excursions at the Permian-Triassic boundary: evidence for upwelling of sulfidic deepocean water masses. Geochemistry, Geophysics, Geosystems 9, 004025.

Almeida, de F.F.M., 1964. Fundamentos geológicos do relevo paulista. Boletim do Instituto Geográfico e Geológico 41, 169-263.

Alroy, J., Aberhan, M., Bottjer, D.J., Foote, M., Fiirsich, F.T., Harries, P.J., Hendy, A.J.W., Holland, S.M. Ivany, LC. Kiessling W. Kosnik, M.A. Marshall, C.R. McGowan, AJ. Miller, A.I., Olszewski, T.D., Patzkowsky, M.E., Peters, S.E., Villier, L., Wagner, P.J., Bonuso, N., Borkow, P.S., Brenneis, B., Clapham, M.E., Fall, L.M., Ferguson, C.A., Hanson, V.L., Krug, A.Z., Layou, K.M., Leckey, E.H., Nürnberg, S., Powers, C.M., Sessa, J.A., Simpson, C., Tomasovych, A., Visaggi, C.C., 2008. Phanerozoic trends in the global diversity of marine invertebrates. Science 321, 97-100.

Andrusevich, V.E., Engel, M.H., Zumberge, J.E., 2000. Effects of paleolatitude on the stable carbon isotope composition of crude oils. Geology 28, 847-885.

Araújo, L.M., 2001. Análise da expressão estrátigrafica dos parametros de geoquimica orgânica e inorgânica nas sequências deposicionais Iratí. (Unpublished Ph.D. thesis) Universidade Federal do Rio Grande do Sul, Brazil (305 pp.).

Araújo, L.M., Trigüis, J.A., Cerqueira, J.R., da S. Freitas, L.C., 2000. The atypical Permian petroleum system of the Parana Basin, Brazil. Petroleum Systems of the South Atlantic margins. In: Mello, M.R., Katz, B.J. (Eds.), Am. Assoc. Petrol. Geol. Mem, 73, pp. 377-402.

Assine, M.L., Piranha, J.M., Carneiro, C.D.R., 2004. Os paleodesertos Pirambóia e Botucatu. In: Mantesso Neto, V., Bartorelli, A., Carneiro, C.D.R., Brito Neves, B.B. (Eds.), Geologia do Continente Sul-Americano: Evolução da obra de Fernando Flávio Marques de Almeida. Beca Prod Cult Ltda, SP, Brasil, pp. 77-92.

Baud, A., Magaritz, M., Holser, W.T., 1989. Permian-Triassic of the Tethys: carbon isotope studies. Geologische Rundschau 78, 649-677.

Berner, R.A. 2002. Examination of hypotheses for the Permo-Triassic boundary extinction by carbon cycle modelling. Proceedings of the National Academy of Sciences of the United States of America 99, 4172-4177.

Bowring, S.A., Erwin, D.H., Jin, Y.G., Martin, M.W., Davidek, K., Wang, W., 1998. U/Pb Zircon geochronology and tempo of the end-Permian mass extinction. Science 280, $1039-1045$

Buffett, B.A., 2006. Clathrate Hydrates. Annu. Rev. Earth Planet. Sci. 2000. 28, 477-507. 
Cao, Chang-qun, Love, G.D., Hays, L.E., Wang, Wei, Shen, Shu-zhong, Summons, R.E., 2009. Biogeochemical evidence for euxinic oceans and ecological disturbance presaging the end Permian mass extinction event. Earth and Planetary Science Letters 281, 188-201.

Cernuschi, F., Gaucher, C., Sial, A.N., Beri, A., 2006. First Carbon and Oxygen isotopic analyses of carbonates from the San Gregorio and Melo Formations (CarboniferousPermian, Parana Basin, Uruguay): paleoenvironmental implications. $5^{\text {th }}$ Symp. S. Amer. Isotope Geosci. Montevideo, Uruguay, pp. 235-239.

Chamani, M.A.C., Martin, M.A.B., Riccomini, C., 1992. Estruturas de liqüefação induzidas por abalos sísmicos no permo-triássico da Bacia do Paraná, Estado de São Paulo, Brasil. Congresso Brasileiro de Geologia, 37, São Paulo. Bol. Res. Expandidos. São Paulo, 2, pp. 508-510.

Collins, G.S., Melosh, J.H., Marcus, R.A., 2005. Earth impact effects program: a web-based computer program for calculating the regional environmental consequences of a meteoroid impact on Earth meteor. Planetary Science 40, 817-840.

Day, S., Maslin, M., 2005. Linking large impacts, gas hydrates, and carbon isotope excursions. Special Paper of the Geological Society of America 384, 239-258.

de Giovani, W.F., Salati, E., Marini, O., Friedman, I., 1974. Unusual isotopic composition of carbonates from the Iratí Formation, Brazil. Geological Society of America Bulletin 85, 41-44.

Dickens, G.R., 2001. The potential volume of oceanic methane hydrates with variable external conditions. Organic Geochemistry 32, 1179-1193.

Dickens, G.R., Quinby-Hunt, M.S., 1997. Methane hydrate stability in pore water: a simple theoretical approach for geophysical applications. Journal of Geophysical Research $102,773-783$

Dickens, G.R., O'Neil, J.R., Rea, D.K., Owen, R.M., 1995. Dissociation of oceanic methane hydrate as a cause of the carbon isotope excursion at the end of the Paleocene. Paleoceanography 10, 965-971.

Dyni, J.R., 2006. Geology and resources of some world oil-shale deposits. Scientific Investigations Report 2005-5294.U.S. Geol. Survey, Reston, Virginia, USA.

Erwin, D.H., 1993. The Great Paleozoic Crisis. Cambridge Univ, Press, New York.

Erwin, D.H., Bowring, S.A., Jin, Y.G., 2002. End-Permian mass extinctions: a review. Catastrophic Events and Mass Extinctions: Impacts and Beyond. In: Koeberl, C., MacLeod, K.G. (Eds.), Geol. Soc. Amer. Spec. Pap., 356, pp. 363-383.

Faure, K., Cole, D., 1999. Geochemical evidence for lacustrine microbial blooms in the vast Permian Main Karoo, Paraná, Falkland Islands and Huab basins of southwestern Gondwana. Palaeogeography, Palaeoclimatology, Palaeoecology 152, 189-213.

Fernandes, L.A., Coimbra, A.M., 1993. Registros de episodios sismicos na parte superior da Formacao Rio do Rasto no Parana, Brasil. Simposio de Geologia do Sudeste, 3, Rio de Janeiro. Atas. SBG/UERJ, Rio de Janeiro, pp. 271-275.

Ganino, C., Arndt, N.T., 2009. Climate changes caused by degassing of sediments during the emplacement of large igneous provinces. Geology 37, 323-326.

Goericke, R., Fry, B., 1994. Variation of marine plankton $\mathrm{d}^{13} \mathrm{C}$ with latitude, temperature, and dissolved CO2 in the world ocean. Global Biogeochemical Cycles 8, 85-90.

Grice, K., Cao, C., Love, G.D., Böttcher, M.E., Twitchett, R.J., Grosjean, E., Summons, R.E., Turgeon, S.C., Dunning, W., Jin, Y., 2005. Photic zone euxinia during the PermianTriassic superanoxic event. Science 307, 706-709.

Hallam, A., 1992. Phanerozoic Sea-level Changes. Columbia University Press, New York (266 pp.).

Hayes, J.M., Strauss, H., Kaufman, A.J., 1999. The abundance of ${ }^{13} \mathrm{C}$ in marine organic matter and isotopic fractionation in the global biogeochemical cycle of carbon during the past 800 Ma. Chemical Geology 161, 103-125.

Hsü, K.J., McKenzie, J.A., 1990. Carbon-isotope anomalies at era boundaries; global catastrophes and their ultimate cause. In: Sharpton, V.L., Ward, P.D. (Eds.), Global Catastrophes in Earth History; an Interdisciplinary Conference on Impacts, Volcanism, and Mass Mortality. Geol. Soc. Amer. Spec. Pap., 247, pp. 61-70.

Irwin, H., Curtis, C., Coleman, M., 1977. Isotopic evidence for source of diagenetic carbonates formed during burial of organic-rich sediments. Nature 269, 209-213.

Isozaki, Y., 1997. Permo-Triassic boundary superanoxia and stratified superocean: records from lost deep-sea. Science 276, 235-238.

Jin, Y.G., Wang, Y., Wang, W., Shang, Q.H., Cao, C.Q., Erwin, D.H., 2000. Pattern of marine mass extinction near the Permian-Triassic boundary in South China. Science 289, 432-436.

Katz, M.E., Pak, D.K., Dickens, G.R., Miller, K.G., 1999. The source and fate of massive carbon input during the latest Paleocene thermal maximum. Science 286, 1531-1534.

Keefer, D.K., 1984. Landslides caused by earthquakes. Geological Society of America Bulletin 95, 406-421.

Kent, D.V., Cramer, B.S., Lanci, L., Wang, D., Wright, J.D., Van der Voo, R., 2003. A case for a comet impact trigger for the Paleocene/Eocene thermal maximum and carbon isotope excursion. Earth and Planetary Science Letters 211, 13-26.

Kerridge, J.F., 1985. Carbon, hydrogen and nitrogen in carbonaceous chondrites: abundances and isotopic compositions in bulk samples. Geochimica et Cosmochimica Acta 49, 1707-1714.

Knoll, A.H., Bambach, R.K., Canfield, D.E., Grotzinger, J.P., 1996. Comparative Earth history and Late Permian mass extinction. Science 273, 452-457.

Korte, C., Kozur, H.W., 2010. Carbon-isotope stratigraphy across the Permian-Triassic boundary: a review. Journal of Asian Earth Sciences 39, 215-235.

Korte, C., Pande, P., Kalia, P., Kozur, H.W. Joachimski, M.M., Oberhänsli, H., 2010. Massive volcanism at the Permian-Triassic boundary and its impact on the isotopic composition of the ocean and atmosphere. Journal of Asian Earth Sciences 37, 293-311.

Krull, E.S., Retallack, G.J., 2000. $\delta^{13} \mathrm{C}$ depth profiles across the Permian-Triassic boundary: evidence for methane release. Geological Society of America Bulletin 112, 1459-1472.

Krull, E.S., Retallack, G.J., Campbell, H.J., Lyon, G.L., 2000. $\delta^{13} \mathrm{C}_{\mathrm{org}}$ chemostratigraphy of the Permian-Triassic boundary in the Maitai Group, New Zealand: evidence for high- latitudinal methane release. New Zealand Journal of Geology and Geophysics 43, 21-32.

Kump, L.R., 1991. Interpreting carbon-isotope excursions: Strangelove oceans. Geology 19, 299-302.

Kump, L.R., Pavlov, A., Arthur, M.A., 2005. Massive release of hydrogen sulfide to the surface ocean and atmosphere during intervals of oceanic anoxia. Geology 33, 397-400

Lana, C., Souza Filho, C.R., Marangoni, Y.R., Yokoyama, E., Trindade, R.I.F., Tohver, E. Reimold, W.U., 2007. Insights into the morphology, geometry, and post-impact erosion of the Araguainha peak-ring structure, central Brazil. Geological Society of America Bulletin 119, 1135-1150.

Lana, C., Souza Filho, C.R., Marangoni, Y.R., Yokoyama, E., Trindade, R.I.F., Tohver, E. Reimold, W.U., 2008. Structural evolution of the $40 \mathrm{~km}$ wide Araguainha impact structure, central Brazil. Meteoritics \& Planetary Science 43, 701-716.

Lanci, L., Tohver, E., Wilson, A., Flint, S., 2013. Magnetostratigraphy and U-Pb geochronology of upper Permian Beaufort Group, Karoo Basin, South Africa. Earth and Planetary Science Letters. http://dx.doi.org/10.1016/j.epsl.2013.05.017.

Lay, T., Kanamori, H., Ammon, C.J., Nettles, M., Ward, S.N., Aster, R.C., Beck, S.L., Bilek, S.L., Brudzinski, M.R., Butler, R., DeShon, H.R., Ekström, G., Satake, K., Sipkin, S., 2005. The Great Sumatra-Andaman Earthquake of 26 December 2004. Science 308, 1127-1133.

Lindström, M., Ormö, J., Sturkell, E., 2008. Water-blow and resurge breccias at the Lockne marine-target impact structure. In: Evans, K.R., Horton Jr., J.W., King Jr., D.T., Morrow J.R. (Eds.), The Sedimentary Record of Meteorite Impacts. Geol. Soc. Amer. Spec. Pap., 437, pp. 43-54.

Macleod, B., 1982. Gas hydrates in ocean bottom sediments. American Association of Petroleum Geologists Bulletin 66, 2649-2662.

MacLeod, K.G., Smith, R.M.H., Koch, P.L., Ward, P.D., 2000. Timing of mammal-like reptile extinctions across the Permian-Triassic boundary in South Africa. Geology 28 227-230.

Magaritz, M., Krishnamurty, R.V., Holser, W.T., 1992. Parallel trends in organic and inorganic carbon isotopes across the Permian/Triassic boundary. American Journal of Science 292, 727-739.

Matos, S.L.F., Coimbra, A.M., 1997. Sucessão de facies na camada Porongaba, Grupo Passo Dois, Estado de São Paulo. Revista Brasileira de Geociencias 27, 377-386.

Melosh, H.J., 1989. Impact cratering: a geologic process. Oxford Monographs on Geology and Geophysics 11, 253.

Messenger, S., 2000. Identification of molecular-cloud material in interplanetary dust particles. Nature 404, 968-971.

Milani, E.J., de Wit, M.J., 2007. Correlations between classic Paraná and Cape-Karoo basins of South America and southern Africa and their basin infills flanking the Gondwanides: Du Toit revisited. In: Pankhurst, R.J., Trouw, R.A.J., de Brito Neves, B.B., de Wit, M.J. (Eds.), West Gondwana: Pre-Cenozoic Correlations Across the South Atlantic Region. Geol. Soc. Spec. Pub, 294, pp. 319-342.

Milani, E.J., Gonçalves de Melo, J.H., Souza, P.A., Fernandes, L.A., França, A.B., 2007. Bacia do Parana. Boletim de Geociências da Petrobrás 15, 265-287.

Montenat, C., Barrier, P., Ott d'Estevou, P., Hibsch, C., 2006. Seismites: an attempt at critical analysis and classification. Sedimentary Geology 196, 5-30.

Mundil, R., Ludwig, K.R., Metcalfe, I., Renne, P.R., 2004. Age and timing of the Permian mass extinctions: U/Pb Dating of closed-system zircons. Science 305, 1760-1763.

Ogg, J.G., Ogg, G., Gradstein, F.M., 2008. The Concise Geologic Time Scale. Cambridge University Press, New York (177 pp.).

Opdyke, N.D., Channell, J.E.T., 1996. Magnetic Stratigraphy. Academic Press, San Diego (346 pp.).

Payne, J.L., Kump, L.R., 2007. Evidence for recurrent early Triassic massive volcanism from quantitative interpretation of carbon isotope fluctuations. Earth and Planetary Science Letters 256, 264-277.

Payne, J.L., Lehrmann, D.L., Wei, J., Orchard, M.J., Schrag, D.P., Knoll, A.H., 2004. Large perturbations of the carbon cycle during recovery from the end-Permian extinction. Science 305, 506-509.

Raup, D.M., Sepkoski Jr., J.J., 1982. Mass extinctions in the marine fossil record. Science 215, 1501.

Reichow, M.K., Pringle, M.S., Al'Mukhamedov, A.I., Allen, M.B., Andreichev, V.L., Buslov, M.M., Davies, C.E., Fedoseev, G.S., Fitton, J.G., Inger, S., Medvedev, A.Ya., Mitchell, C., Puchkov, V.N., Safonova, I.Yu., Scott, R.A., Saunders, A.D., 2009. The timing and extent of the eruption of the Siberian Traps large igneous province: implications for the endPermian environmental crisis. Earth and Planetary Science Letters 277, 9-20.

Renne, P.R., Basu, A.R., 1991. Rapid eruption of the Siberian Traps flood basalts at the Permo-Triassic boundary. Science 253, 176-179.

Renne, P.R., Zhang, Z., Richards, M.A., Black, M.T., Basu, A.R., 1995. Synchrony and causal relations between Permian-Triassic boundary crises and Siberian flood volcanism. Science 269, 1413-1416.

Retallack, G.J., Jahren, A.H., 2008. Methane release from igneous intrusion of coal during Late Permian extinction events, J. Geology 116, 1-20.

Retallack, G.J., Krull, E.S., 2006. Carbon isotopic evidence for terminal-Permian methane outbursts and their role in extinctions of animals, plants, coral reefs and peat swamps. In: Greb, S.F., DiMichele, W.A. (Eds.), Wetlands through time. Geol. Soc. Amer. Spec. Pap., 399, pp. 249-268.

Riccomini, C., Chamani, M.A.C., Agena, S.S., Fambrini, G.L., Fairchild, T.R., Coimbra, A.M., 1992 Earthquake-induced liquefaction features in the Corumbataí Formation (Permian, Paraná Basin, Brazil) and the dynamics of Gondwana. Anais da Academia Brasileira de Ciências 64, 210.

Riccomini, C., Almeida, R.P., Turra, B.B., Chamani, M.A.C., Fairchild, T.R., Hachiro, J., 2005 Reativação de falha do embasamento causa sismicidade no Permotriássico da Bacia do Paraná. Inter. Symp. Tect. Braz. Geol. Soc. Curitiba, pp. 18-20.

Rodrigues, R., Pereira, E., Bergamachi, S., Alferes, C.L.F., 2010. Carbon isotope stratigraphy of organic matter: Irati Formation. Lower Permian of Paraná Basin VII South American Symposium on Isotope Geology, Brasília, 25th-28th July 2010, pp. 522-525. 
Rothwell, R.G., Thomson, J., Kähler, G., 1998. Low-sea-level emplacement of a very large Late Pleistocene 'megaturbidite' in the western Mediterranean Sea. Nature 392, 26-28.

Ryskin, G., 2003. Methane-driven oceanic eruptions and mass extinctions. Geology 31, 741-744.

Santos, R.V., Souza, P.A., Alvarenga, C.J.S., Dantas, E.L., Pimentel, M.M., de Oliveira, C.G., Araújo, L.M., 2006. Shrimp U-Pb zircon dating and palynology of bentonitic layers frm the Permian Irati Formation, Paraná Basin, Brazil. Gondwana Research 9, 456-463.

Santos, R.V Dantas, E. L Oliveira, C.G. Alvarenga, C.JS, Dias dos Anjos, C.W., Guimarães, E.M., Oliveira, F.B., 2009. Geochemical and thermal effects of a basic sill on black shales and limestones of the Permian Irati Formation. Journal of South American Earth Sciences 28, 14-24.

Saunders, A., Reichow, M., 2009. The Siberian Traps and the End-Permian mass extinction: a critical review. Chinese Science Bulletin 54, 20-37.

Shen, S.Z., Crowley, J.L., Wang, Y., Bowring, S.A., Erwin, D.H., Sadler, P.M., Cao, C.Q. Rothman, D.H., Henderson, C.M., Ramezani, J., Zhang, H., Shen, Y., Wang, X.D. Wang, W., Mu, L., Li, W.Z., Tang, Y.G., Liu, X.L., Liu, L.J., Zeng, Y., Jiang, Y.F., Jin, Y.G., 2011. Calibrating the end-Permian mass extinction. Science 334, 1367-1372.

Simms, M.J., 2003. Uniquely extensive seismite from the latest Triassic of the United Kingdom: evidence for bolide impact? Geology 31, 557-560.

Sobolev, S.V., Sobolev, A.V., Kuzmin, D.V., Krivolutskaya, N.A., Petrunin, A.G., Arndt, N.A. Radko, V.A., Vasiliev, Y.R., 2011. Linking mantle plumes, large igneous provinces and environmental catastrophes. Nature 477, 312-316.

Soria, A.R., Liesal, C.L., Mata, M.P., Arz, J.A., Alegret, L., Arenillas, I., Meléndez, A., 2001 Slumping and a sandbar deposit at the Cretaceous-Tertiary boundary in the E Tecolote section (northeastern Mexico): an impact-induced sediment gravity flow. Geology 29, 231-234.

Spray, J.G., 1997. Superfaults. Geology 25, 579-582.

Surlyk, F., Gjelberg, J., Noe-Nygaard, N., 2007. The Upper Jurassic Hareelv Formation of East Greenland: a giant sedimentary injection complex. In: Hurst, A., Cartwright, J. (Eds.), Sand Injectites: Implications for Hydrocarbon Exploration and Production. Am. Assoc. Petrol. Geol. Mem, 87, pp. 141-149.

Svensen, H., Planke, S., Polozov, A.G., Schmidbauer, N., Corfu, F., Podladchikov, Y.Y. Jamtveit, B., 2009. Siberian gas venting and the end-Permian environmental crisis. Earth and Planetary Science Letters 277, 490-500.
Tanner, L.H., 2010. The Triassic isotope record. Geological Society of London Special Publication 334, 103-118.

Tohver, E., Lana, C., Cawood, P.A., Fletcher, I., Sherlock, S., Jourdan, F., Rasmussen, B., Trindade, R.I.F., Yokoyama, E., Souza Filho, C.R., Marangoni, Y., 2012. Geochronological constraints on a Permo-Triassic impact crater: $\mathrm{U}-\mathrm{Pb}$ and ${ }^{40} \mathrm{Ar} /{ }^{39} \mathrm{Ar}$ results from the $40 \mathrm{~km}$ Araguainha crater of central Brazil. Geochimica et Cosmochimica Acta 86, 214-227.

Toon, O.B., Zahnle, K., Morrison, D., Turco, R.P., Covey, C., 1997. Environmental perturbation caused by the impact of asteroids and comets. Reviews of Geophysics $35,41-58$.

Turra, B.B., 2009. Diques clásticos da Formação Corumbataí, Bacia do Paraná, no contexto da tectônica Permo-Triassico do Gondwana Ocidental. (Unpublished MSc. thesis) Universidade de São Paulo, Brazil (100 pp.).

Valencio, D.A., Rocha Campos, A.C., Pacca, I.G., 1975. Paleomagnetism of some sedimentary rocks of the late Paleozoic Tubarão and Passa Dois Groups from the Paraná Basin, Brazil. Revista Brasileira de Geociencias 5, 186-197.

Veizer, J., Ala, D., Azmy, K., Bruckschen, P., Buhl, D., Bruhn, F., Carden, G.A.F., Diener, A., Ebneth, S., Godderis, Y., Jasper, T., Korte, C., Pawellek, F., Podlaha, O., Strauss, H., 1999. ${ }^{87} \mathrm{Sr} /{ }^{86} \mathrm{Sr}$, $\mathrm{d}^{13} \mathrm{C}$ and $\mathrm{d}^{18} \mathrm{O}$ evolution of Phanerozoic seawater. Chemical Geology 161, 59-88.

Wang, K., Geldsetzer, H.H.J., Krouse, H.R., 1994. Permian-Triassic extinction: organic $\delta^{13} \mathrm{C}$ evidence from British Columbia, Canada. Geology 22, 580-584.

Whiticar, M.J., 1999. Carbon and hydrogen isotope systematics of bacterial formation and oxidation of methane. Chemical Geology 161, 291-314.

Wilson, R.C., Keefer, D.K., 1985. Predicting areal limits of earthquake induced landsliding. Evaluating Earthquake Hazards in the Los Angeles Region - An Earth Science Perspective. USGS Prof. Pap., 1360, pp. 316-345.

Witzke, B.J., Anderson, R.R., 1996. Sedimentary-clast Breccias of the Manson Impact Structure, Iowa: Anatomy of an Impact Crater. In: Koeberl, C., Anderson, R.R. (Eds.), Geol. Soc. Amer. Spec. Pap., 302, pp. 115-142.

Xie, S., Pancost, R.D., Huang, J., Wignall, P.B., Yu, J., Tang, X., Chen, L., Huang, X., Lai, X., 2007. Changes in the global carbon cycle occurred as two episodes during the Permian-Triassic crisis. Geology 35, 1083-1086.

Yin, H., Zhang, K., Tong, J., Yang, Z., Wu, S., 2001. The Global Stratotype Section and Point (GSSP) of the Permian-Triassic Boundary. Episodes 24, 12. 